\title{
Interaction of Substrates and Inoculants for Samanea Saman (Jacq.) Merr Seedling Production
}

\author{
Gustavo Wyse Abaurre ${ }^{1}$ \\ Orivaldo José Saggin Júnior² ${ }^{2}$ \\ Sergio Miana de Faria ${ }^{3}$ (D) \\ ${ }^{1}$ Universidade Federal Rural do Rio de Janeiro, Jardim Botânico, Seropédica, RJ, Brasil. \\ ${ }^{2}$ EMBRAPA, Centro Nacional de Pesquisa de Agrobiologia, Laboratório de Micorrizas, Seropédica, RJ, Brasil. \\ ${ }^{3}$ EMBRAPA, Centro Nacional de Pesquisa de Agrobiologia, Laboratório de Leguminosas Florestais, Seropédica, RJ, Brasil.
}

\begin{abstract}
The objective of this study was to evaluate the effect of the inoculation with nitrogen-fixing bacteria (NFB) and arbuscular mycorrhizal fungi (AMF) and substrates in the production of Samanea saman (rain tree) seedlings. Three substrates and three inoculation treatments were combined in a randomized block design with six repetitions. The Sewage Sludge substrate favored symbiosis with AMF (promoting twelve times more sporulation), while the Commercial substrate favored symbiosis with NFB (promoting $70 \%$ more nodulation). The Sewage Sludge substrate provided the best development of $S$. saman seedlings, as it promoted higher biomass compared to the Commercial and Standard substrates (14\% and 150\% respectively). The most significant response to inoculation occurred in the seedlings produced in the Standard substrate, in which the inoculated seedlings had higher biomass than those that received fertilization and those that received neither inoculation nor fertilization ( $20 \%$ and $50 \%$ respectively).
\end{abstract}

Keywords: Arbuscular mycorrhizal fungi, Nitrogen-fixing bacteria, Biosolids, Root symbiosis, Rain tree.

\section{INTRODUCTION AND OBJECTIVES}

At the 11th United Nations Framework Convention on Climate Change held in Paris in 2015, Brazil committed to ingrestoring 12 million hectares of forest by 2030 (Scaramuzza et al., 2016). The cost to reach this goal is estimated to range between $\mathrm{R} \$ 31$ and $\mathrm{R} \$ 52$ billion depending on the projected scenario (Kishinami \& Shigueo, 2016). Considering the sizeable amount of national investment planned for the next ten years, it is essential to research to develop techniques capable of reducing the forest restoration plantations costs. These include the inoculation of microorganisms that promote plant growth and nutrition, as nitrogen-fixing bacteria (NFB) and arbuscular mycorrhizal fungi (AMF).

NFB enable the use of atmospheric nitrogen, reducing the use of fertilizers and increasing the growth of forest legumes. Additionally, in mixed plantations, $\mathrm{N}$ fixing plants provide higher amounts of this nutrient and positively influence nonfixing plants (de Faria et al., 2020). On the other hand, AMF increase the absorption of water and nutrients of their host plants as they function as an efficient extension of the root system, facilitating the establishment of seedlings in the field (Hoffman \& Lucena, 2006). In forest plantations, the presence of AMF balances the growth of plant species, avoiding the dominance of the most adapted individuals (Santos, 2008).

Several authors have studied the effect of NFB and AMF inoculation on forest leguminous. Reports include increased height and diameter of Mimosa caesalpiniaefolia (Mendes et al., 2013), higher biomass production of Mimosa scabrella seedlings (Primieri et al., 2015) and improved development of Acacia mangium seedlings (Andraus et al., 2020).

Samanea saman (rain tree) is a leguminous species with natural occurrence in tropical forests of Brazil, Peru, Paraguay, and Bolivia (Lorenzi, 1998). It is widely used in forest restoration projects (dos Santos \& Maneschy, 2016; Góes \& Quintela, 2015), It has medicinal properties (Prasad et al., 2008), and the fruits used for cattle feeding (Lorenzi, 1998 ). S. saman tolerates flooded environments and resists periods of drought. It is also flexible regarding soil fertility, showing profitable growth under low nutrient and $\mathrm{pH}$ levels 
(Barwick et al., 2004). When it comes to its symbiosis with rhizobia, S. saman is considered a promiscuous species, able to associate with several bacterial genera and families capable of fixing atmospheric nitrogen (de Faria et al., 2020). Inoculation with Bradyrhizobium elkanii BR 6205 and BR 6212 , is however indicated for seedling production (Brasil, 2011). Although seed germination rate is low, it exceeds $90 \%$ when seeds are subjected to chemical scarification with sulfuric acid (Nascimento \& Oliveira, 1999). Seedlings can be produced in organic sandy soils (Lorenzi, 1998) and can reach $33 \mathrm{~cm}$ in height, $5.2 \mathrm{~mm}$ in the stem diameter and $4.6 \mathrm{~g}$ of total dry mass at 195 days after sowing (Abaurre et al., 2020). Staples \& Craig (2006) suggest that the seedlings are ready for planting between 90 and 150 days after sowing when they reach a height between $20-30 \mathrm{~cm}$ and stem diameter greater than $4 \mathrm{~mm}$.

Abaurre et al. (2020) testing nine substrates identified that the symbiosis of S. saman with AMF and NFB is favoured when seedlings are produced in Carolina Soil Standard 0.7 and Sewage sludge substrate. Carolina Soil Standard 0.7 is a commercial substrate composed of sphagnum peat moss, vermiculite, and carbonized rice husk. The Sewage sludge substrate is supplied by the State Water and Sewage Company of Rio de Janeiro (CEDAE).

Previous studies evaluated and recommended the most promising substrates to favor NBF and AMF inoculation in S. saman seedlings (Abaurre et al., 2020). It is necessary to advance the knowledge comparing the effects of inoculants and the traditional chemical fertilizers in seedlings' growth. For this reason, the present study evaluated the interaction of different substrates with or without the presence of NFB and AMF inoculation and fertilization to produce $S$. saman seedlings.

Besides evaluating the effects of plant growth-promoting microorganisms (PGPM), this study also evaluates the use of sewage sludge as a substrate for tree seedlings. Thus, the manuscript has the value of combining two trends (PGPM inoculation and waste reusing alternatives) in modern science (Fijalkowski \& Kwarciak-Kzlowska, 2021, Freire et al., 2020).

\section{MATERIALS AND METHODS}

The experiment was conducted between December 2017 and April 2018, with a total duration of 130 days, in a greenhouse located at the Federal Rural University of Rio de Janeiro, Seropédica, RJ, Brazil ( $22^{\circ} 45^{\prime} 33.29^{\prime \prime}$ S, $43^{\circ} 40^{\prime} 48.90^{\prime \prime}$ $\mathrm{W}$ ). The greenhouse had the cooling system (air humidifying panel and exhaust fan) automatically turned on when the internal temperature reached $35^{\circ} \mathrm{C}$ and turned off when it reached $28^{\circ} \mathrm{C}$.

The experiment was implemented in a randomized block design in a factorial scheme $(3 \times 3)$ corresponding to three substrates and three inoculation treatments with six replications, with each plot consisting of nine S. saman seedlings.

The inoculation treatments were: a) double inoculation with NFB and AMF; b) seedlings produced without inoculants and fertilized with $111 \mathrm{mg}$ of $\mathrm{N}, 16 \mathrm{mg}$ of $\mathrm{P}_{2} \mathrm{O}_{5}$ and $51 \mathrm{mg}$ of $\mathrm{K}_{2} \mathrm{O}$ per seedling, divided into ten weekly fertigations between 31 and 93 days after sowing (Positive Control); and c) seedlings neither inoculated nor fertilized (Absolute Control). Bradyrhyzobium elkanii BR 6205 and BR 6212 strains were used as the NFB, following the recommendation of the Ministry of Agriculture, Livestock, and Supply for the production of Samanea saman seedlings (Brazil, 2011). The peat inoculant containing the NFB strains $\left(10^{7} \mathrm{CFU} / \mathrm{g}\right)$ was mixed with the seeds $(1.0 \mathrm{~g} / \mathrm{kg})$ at the time of planting. Inoculation with AMF was done through application in each seedling of a mixed inoculant of nine species containing approximately five spores of each species of the following strains: A97 Acaulospora colombiana; A96 Acaulospora morrowiae; A38 Acaulospora scrobiculata; A2 Dentiscutata heterogama; A36 Gigaspora candida; A20 Glomus formosanum; A5 Rhizophagus clarus; A80 Scutellospora calospora and A75 Scutellospora gilmorei. The soil was used as a carrier for this inoculant and in addition to the spores counted, there were also fragments of colonized roots and hyphae (which were not counted). Both inoculants were provided by the Johanna Döbereiner Biological Resource Center (CRB-JD) of Embrapa Agrobiology.

The substrates used were: a) Standard: clay subsoil 66\% and bovine manure $33 \%(\mathrm{~V} / \mathrm{V})$, which was used a control; b) Commercial: Carolina Soil Standard 0.7, composed of sphagnum peat moss, vermiculite, and carbonized rice husk; and c) Sewage sludge: sewage sludge supplied by the State Water and Sewage Company of Rio de Janeiro (CEDAE). The substrates used were autoclaved and chemically analyzed (Table 1). 
Table 1. Chemical characteristics of the substrates analyzed through the soil fertility analysis methodology (Nogueira et al., 1998).

\begin{tabular}{|c|c|c|c|c|c|c|c|c|}
\hline \multirow{2}{*}{ Substrate } & \multirow{2}{*}{$\underset{\left(\mathbf{H}_{2} \mathbf{O}\right)}{\mathbf{p H}}$} & $\mathbf{N}_{\text {pot }}$ & $\mathbf{P}$ & $\mathbf{K}$ & $\mathrm{Ca}$ & Mg & $\mathbf{H}+\mathbf{A l}$ & Al \\
\hline & & \multicolumn{3}{|c|}{$\mathrm{mg} \mathrm{L}^{-1}$} & \multicolumn{4}{|c|}{$\mathrm{cmol}_{\mathrm{c}} \mathrm{dm}^{-3}$} \\
\hline Standard & 7.4 & 98 & 81 & 729 & 3.2 & 1.8 & 1.3 & 0.0 \\
\hline Commercial & 5.4 & 141 & 193 & 313 & 3.5 & 15.0 & 5.5 & 0.3 \\
\hline Sewage sludge & 5.1 & 409 & 388 & 189 & 3.6 & 1.3 & 10.2 & 0.1 \\
\hline
\end{tabular}

Npot. = nitrogen potentially available to plants (nitrate + ammonium + nitrite + labile organic forms); Methodologies used in the analyses: Npot. (extraction in $\mathrm{KCl}$, determination by acid digestion - Kjeldahl); Available P (extraction by Mehlich I, determination by colorimetry); Exchangeable K (Mehlich I extraction, flame photometry determination); Exchangeable $\mathrm{Ca}$ and $\mathrm{Mg}$ (extraction by $\mathrm{KCl} \mathrm{MM}$ and determination by atomic absorption spectrometry); Potential acidity ( $\mathrm{H}+\mathrm{Al})$ and $\mathrm{Al}$ (extraction by $\mathrm{KCl} 1 \mathrm{M}$ and determination by titration).

The seedling containers used were $280 \mathrm{~cm}^{3}$ cone-tainers, superficially disinfected by immersion in a $3 \%$ sodium hypochlorite solution for 1 hour. The cone-tainers were supported on a 54-cell tray (6 rows of 9 cells). Each tray was only occupied by two experimental plots (two lines of 9 cells).

The seedlings were irrigated daily with autoclaved distilled water by applying $7.5 \mathrm{ml} /$ cone-tainer. The height and stem diameter of the seedlings were measured 113 days after sowing. The plants were harvested 130 days after sowing, dried in a forced circulation oven $\left(65-70^{\circ} \mathrm{C}\right)$ and weighed. For the root system, a sample of approximately $0.5 \mathrm{~g}$ of fresh thin roots was separated previously to drying to assess the root mycorrhizal colonization rate. These samples were clarified and stained according to Koske \& Gemma (1989) and Grace \& Stribley (1991), respectively. The colonization rate was estimated, according to McGonigle et al. (1990). The mass of the fresh roots sampled to evaluate colonization was used to correct the total root dry mass. For each substrate, the inoculation response was calculated by dividing the seedling total dry mass of the inoculated treatment by seedling total dry mass of the Absolute Control treatment.

AMF spores were extracted from $50 \mathrm{ml}$ substrate samples through wet sieving (Gerdemann \& Nicolson, 1967) and consecutive centrifugations in water and sucrose solution (Jenkins, 1964), after which the spores were counted under a stereomicroscope.

The data were subjected to normality (Shapiro-Wilk), and homogeneity of variance (Bartlett) tests using the $\mathrm{R}$ software program. These were followed by the analysis of variance (two-way ANOVA), and Scott-Knott means comparison test at $5 \%$ probability of error, both conducted using SISVAR 5.6.

\section{RESULTS AND DISCUSSION}

The analysis of variance indicated a significant interaction between inoculation and substrates factors for most of the variables. Root colonization was the exception, as it was only significantly influenced by the inoculation treatments (Table 2).

Although the interaction substrate $\mathrm{x}$ inoculation was significant for shoot, root and seedling total dry mass, these variables showed the same response to the substrates regardless of the inoculation treatment, suggesting a strong and consistent difference between the substrates (Table 3). The Sewage sludge substrate increased biomass production the most, followed by the Commercial substrate. The Standard substrate promoted the lowest growth of the seedlings in relation with other two substrates.

Contrary to seedling growth, the greatest response of the inoculation on the biomass was verified for the Standard substrate of lower fertility, because in this substrate, seedling had a higher shoot and total dry mass when inoculated with NFB and AMF, followed by seedlings that received fertilization. The lowest growth for this substrate was verified in the seedlings from the Absolute Control.

Table 2. Summary of the two-way analysis of variance ( $\mathrm{p}$-value) for variables measured in S. saman seedlings produced in three substrates with three inoculation treatments.

\begin{tabular}{lccc} 
Variables & Substrates & Inoculation & Substrates * Inoculation \\
\hline Root dry mass & 0.0000 & 0.0000 & 0.0037 \\
Shoot dry mass & 0.0000 & 0.0000 & 0.0192 \\
Seedling total dry mass & 0.0000 & 0.0003 & 0.0137 \\
Height & 0.0000 & 0.0757 & 0.0000 \\
Stem diameter & 0.0000 & 0.4333 & 0.0000 \\
Nodule dry mass & 0.0000 & 0.0000 & 0.0004 \\
Root colonization & 0.8530 & 0.0000 & 0.9575 \\
Spore density & 0.0000 & 0.0000 & 0.0000
\end{tabular}

For $p$-value $\leq 0.05$, the effect was considered statistically significant. 
Table 3. Shoot, root, and total dry mass of Samanea saman seedlings produced in three substrates with three inoculation treatments 130 days after sowing.

\begin{tabular}{|c|c|c|c|c|c|c|c|c|c|}
\hline \multirow{2}{*}{ Substrates } & \multicolumn{9}{|c|}{ Inoculation } \\
\hline & \multicolumn{3}{|c|}{ NFB and AMF } & \multicolumn{3}{|c|}{ Positive Control } & \multicolumn{3}{|c|}{ Absolute Control } \\
\hline & \multicolumn{9}{|c|}{ Shoot dry mass $(\mathrm{g}) \mathrm{CV}(\%)=7.2$} \\
\hline Sewage sludge & 5.73 & A & a & 5.31 & A & $\mathrm{b}$ & 5.26 & A & $\mathrm{b}$ \\
\hline Commercial & 5.05 & B & $\mathrm{a}$ & 4.84 & B & a & 4.70 & B & a \\
\hline \multirow[t]{2}{*}{ Standard } & 2.83 & $\mathrm{C}$ & a & 2.04 & $\mathrm{C}$ & $\mathrm{b}$ & 1.68 & $\mathrm{C}$ & $\mathrm{C}$ \\
\hline & \multicolumn{9}{|c|}{ Root dry mass $(\mathrm{g}) \mathrm{CV}(\%)=10.2$} \\
\hline Sewage sludge & 1.65 & A & b & 1.95 & A & a & 1.98 & A & A \\
\hline Commercial & 1.41 & B & $\mathrm{b}$ & 1.73 & B & $\mathrm{a}$ & 1.40 & B & B \\
\hline \multirow[t]{2}{*}{ Standard } & 0.70 & $\mathrm{C}$ & b & 0.89 & $\mathrm{C}$ & a & 0.63 & $\mathrm{C}$ & B \\
\hline & \multicolumn{9}{|c|}{ Seedling total dry mass $(\mathrm{g}) \mathrm{CV}(\%)=7.1$} \\
\hline Sewage sludge & 7.38 & A & a & 7.25 & A & a & 7.24 & A & A \\
\hline Commercial & 6.47 & B & a & 6.57 & B & $\mathrm{a}$ & 6.10 & $\mathrm{~B}$ & A \\
\hline Standard & 3.53 & $\mathrm{C}$ & $\mathrm{a}$ & 2.93 & C & b & 2.30 & $\mathrm{C}$ & $\mathrm{C}$ \\
\hline
\end{tabular}

Means with equal letter, upper case comparing substrates (column) and lower case comparing inoculation treatments (row), do not differ statistically by Scott-Knott test $(\mathrm{P} \leq 0.05)$. $\mathrm{CV}(\%)=$ coefficient of variation of the analysis of variance; $\mathrm{NFB}=$ nitrogen-fixing bacteria; $\mathrm{AMF}=$ arbuscular mycorrhizal fungi.

Fertilization favoured rooting in the Standard and Commercial substrate, whereas in the Sewage sludge substrate (with greater fertility) this effect was not verified. The highest growth of the seedling produced in the Sewage sludge substrate was probably due to higher $\mathrm{N}$ and $\mathrm{P}$ availability (Table 1). Similar results have been documented for by Delarmelina et al. (2014), Gonçalves et al. (2014), Cabreira et al. (2019), Silva et al. (2019) and Lima Filho et al. (2019) for Ateleia glazioviana, Sesbania virgata, Schizolobium parahyba, Luehea divaricata, and Ceiba speciosa, respectively.

Fertilization of the Positive Control treatment increased rooting of the seedlings grown in the Commercial and Standard substrates, but not of those produced in the Sewage sludge, probably due to the high fertility of the latter. In the
Standard substrate which had the lowest fertility, the effect of inoculation with NFB and AMF was evident as it increased the shoot and seedling total biomass.

The results of the seedling height and stem diameter are shown in Table 4 and reflect the initial fertility of the substrates (Table 1). The highest values of height and stem diameter corresponded to the seedlings grown in the Sewage sludge, the substrate with the highest $\mathrm{N}$ and P levels. Seedling height represents one of the leading indicators of initial growth in the field (Caldeira et al., 2014) while stem diameter is one of the leading indicators of root growth and survival after field planting (Santos et al., 2000). Therefore, these two nondestructive variables are the most used to assess the seedling quality of forest species (Ferreira et al., 2019).

Table 4. Height and stem diameter in Samanea saman seedlings produced with three substrate and inoculation treatments at 113 days after sowing.

\begin{tabular}{|c|c|c|c|c|c|c|c|c|c|}
\hline \multirow{3}{*}{ Substrates } & \multicolumn{9}{|c|}{ Inoculation } \\
\hline & \multicolumn{3}{|c|}{ NFB and AMF } & \multicolumn{3}{|c|}{ Positive Control } & \multicolumn{3}{|c|}{ Absolute Control } \\
\hline & \multicolumn{9}{|c|}{ Height $(\mathrm{cm}) \quad \mathrm{CV}(\%)=4.0$} \\
\hline Sewage sludge & 35.2 & $\mathrm{~A}$ & c & 39.1 & A & a & 37.4 & A & $\mathrm{b}$ \\
\hline Commercial & 34.2 & $\mathrm{~A}$ & $\mathrm{a}$ & 32.3 & $\mathrm{~B}$ & $\mathrm{~b}$ & 33.8 & $\mathrm{~B}$ & a \\
\hline \multirow[t]{2}{*}{ Standard } & 28.2 & B & a & 24.8 & $\mathrm{C}$ & $\mathrm{b}$ & 23.4 & $\mathrm{C}$ & $\mathrm{b}$ \\
\hline & \multicolumn{9}{|c|}{ Stem diameter $(\mathrm{mm}) \quad \mathrm{CV}(\%)=3.8$} \\
\hline Sewage sludge & 5.1 & A & $\mathrm{b}$ & 5.5 & A & a & 5.7 & A & a \\
\hline Commercial & 5.0 & A & $\mathrm{a}$ & 5.1 & $\mathrm{~B}$ & $\mathrm{a}$ & 4.9 & $\mathrm{~B}$ & $\mathrm{a}$ \\
\hline Standard & 4.1 & B & $\mathrm{a}$ & 3.7 & $\mathrm{C}$ & b & 3.7 & $\mathrm{C}$ & $\mathrm{b}$ \\
\hline
\end{tabular}

Means with the equal letter, upper case comparing substrates (column) and lower case comparing inoculation treatments (row), do not differ statistically by ScottKnott test $(\mathrm{P} \leq 0.05) . \mathrm{CV}(\%)=$ coefficient of variation of the analysis of variance; $\mathrm{NFB}=$ nitrogen -fixing bacteria; $\mathrm{AMF}=$ arbuscular mycorrhizal fungi.

The moast significant height was verified for S. saman seedlings grown in the Sewage sludge and the Commercial substrate with inoculation (Table 4). In the Sewage sludge, the height exceeded $35 \mathrm{~cm}$ for all the inoculation treatments. It corresponds with results obtained by Gonçalves et al (2014), who suggested plant height as an excellent parameter to indicate seedling quality. This result indicates that in this substrate, the seedlings need less time to reach the proper 
height to be transferred to the field, thereby reducing the cost of production (Simões et al., 2012).

The height in plants grown in the Standard substrate was lower than in the other substrates, even when mineral fertilizer was supplied (Table 4). The main component of the Standard substrate is clay subsoil (66\%). Compaction of this substrate and consequently reduced gas exchange, associated to low nutrient availability might explain these results (Table 1 ), as they are essential factors for seedlings development in cone-tainers (Kämpf, 2005, de Oliveira et al., 2018).

Considering that $S$. saman seedlings are ready to be planted in the field when they reach a height between 20 and $30 \mathrm{~cm}$ and Stem diameter greater than $4 \mathrm{~mm}$ (Staples \& Craig, 2006) it is possible to observe in Table 4 that all seedlings produced on the substrates Commercial and Sewage sludge, had the indicated parameters, however, for the Standard substrate, only the seedlings that received inoculation managed to reach the ideal stem diameter. Therefore, the use of inoculants is necessary for the production of $S$. saman seedlings in the Standard substrate.

Inoculation with NFB and AMF promoted greater nodulation in the seedlings in the Sewage sludge and Standard substrates (Table 5). Mycorrhizal colonization percentages varied from $10 \%$ to $13 \%$ in seedlings that received inoculation, which is low (less than 20\%) according to the classification proposed by Carneiro et al. (1998). On the other hand, spore production was favored in the Sewage sludge, while nodulation was favoured in the Commercial substrate (Table 5). There was no AMF sporulation or colonization in seedlings that did not receive inoculation.

Table 5. Dry nodule mass, root mycorrhizal colonization rate, and AMF spore density of Samanea saman seedlings grown in three substrates with three inoculation treatments 130 days after sowing.

\begin{tabular}{|c|c|c|c|c|c|c|c|c|c|}
\hline \multirow{2}{*}{ Substrates } & \multicolumn{9}{|c|}{ Inoculation } \\
\hline & \multicolumn{3}{|c|}{ NFB and AMF } & \multicolumn{3}{|c|}{ Positive Control } & \multicolumn{3}{|c|}{ Absolute Control } \\
\hline & \multicolumn{9}{|c|}{ Nodule dry mass $(\mathrm{mg})$ CV $(\%)=21.9$} \\
\hline Sewage sludge & 372 & B & a & 25 & B & c & 150 & $\mathrm{~B}$ & $\mathrm{~b}$ \\
\hline Commercial & 656 & A & a & 243 & A & $\mathrm{b}$ & 584 & A & a \\
\hline \multirow[t]{2}{*}{ Standard } & 380 & B & a & 64 & B & c & 170 & B & $\mathrm{b}$ \\
\hline & \multicolumn{9}{|c|}{ Root colonization $(\%)$ CV $(\%)=130.0$} \\
\hline Sewage sludge & 10 & A & a & 0 & A & $\mathrm{b}$ & 0 & A & $\mathrm{b}$ \\
\hline Commercial & 13 & A & $\mathrm{a}$ & 0 & A & $\mathrm{b}$ & 0 & A & $\mathrm{b}$ \\
\hline \multirow[t]{2}{*}{ Standard } & 13 & A & a & 0 & A & $\mathrm{b}$ & 0 & A & $\mathrm{b}$ \\
\hline & \multicolumn{9}{|c|}{ Spore density CV $(\%)=142.0$} \\
\hline Sewage sludge & 411 & A & a & 0 & A & $\mathrm{b}$ & 0 & A & $\mathrm{b}$ \\
\hline Commercial & 22 & B & a & 0 & A & $\mathrm{b}$ & 0 & A & $\mathrm{b}$ \\
\hline Standard & 33 & B & a & 0 & A & $\mathrm{b}$ & 0 & A & $\mathrm{b}$ \\
\hline
\end{tabular}

Means with equal letter, upper case comparing substrates (column) and lower case comparing inoculation treatments (row), do not differ statistically by Scott-Knott test $(\mathrm{P} \leq 0.05) . \mathrm{CV}(\%)=$ coefficient of variation of the analysis of variance; $\mathrm{NFB}=$ nitrogen-fixing bacteria; $\mathrm{AMF}=$ arbuscular mycorrhizal fungi.

Fertilization of plants within the Positive Control reduced nodulation in the seedlings grown in all substrates. It was because the NFB and AMF activities are more evident in the absence of nutrients $\mathrm{N}$ and $\mathrm{P}$, respectively. The presence of these nutrients inhibits the formation of the respective symbioses since the energy cost to perform these symbioses is very high compared to the high availability of these nutrients in the environment (de Faria et al., 2010, de Faria et al., 2020, Smith \& Smith, 1997, Dobereiner, 1984).

Nodules were verified in plants within the Positive and Absolute Controls, which did not receive inoculation (Table 5). However, the dry nodule mass in plants of these treatments was lower than in those of the inoculated treatment. Inoculation with NFB and AMF promoted greater nodulation of the seedlings in plants grown in the Sewage sludge and Standard substrate, but not in those produced in the Commercial substrate, where the nodulation was equal to that of the Absolute Control.

There was no contamination by mycorrhizal fungi, the presence of which was only verified in the treatment with NFB and AMF (Table 5). AMF spores are large and attached to the mycelium, which makes it challenging to move through air and water. The spores of the inoculated species in the present study vary between $60 \mu \mathrm{m}$ (Acaulospora morrowiae) and 280 $\mu \mathrm{m}$ (Gigaspora candida) in diameter (INVAM, 2020). Also, several AMF species produces form sporocarps containing many spores, which are much larger than individual spores, and some species preferentially sporulate within roots (Smith \& Smith, 1997). Thus, the contamination by AMF is more complicated than by NFB.

The results obtained herein are supported by the cited literature and indicate the Sewage sludge as a useful and low- 
cost substrate. Sewage Treatment Stations have large quantities of this waste, and the reuse of it in the production of seedlings contributes to sustainability by reusing a material that would be destined for dumping ground. However, an analysis of the fertility of different Sewage sludges must be conducted to avoid nutritional excess or scarcity for the seedlings.

Even though the Standard substrate favoured plant growth in response to inoculation (Table 3 and 4), results regarding NFB nodulation and AMF sporulation were inferior compared to those of the other two substrates. Symbionts bring greater benefits to the host plant in low fertility substrates (Nogueira et al., 2010), the Standard substrate proves to be ideal for the functioning of these symbioses, presenting a more significant response to inoculation.

The substrates of greater fertility (Sewage sludge and Commercial), enabled the formation of larger seedlings and restricted the response to inoculation. In these two substrates, seedling within the inoculated treatment did not exceed the results obtained for these variables within the Positive and Absolute Controls. The Sewage sludge and the Commercial substrate promoted AMF sporulation and NFB nodulation, respectively, which can be useful when transplanting the seedlings to the field.

\section{CONCLUSIONS}

The Sewage sludge substrate provides more significant seedling development and is conducive to symbiosis with AMF allowing high sporulation;

The Commercial substrate favors symbiosis with NFB, increasing nodulation of $S$. saman seedlings and showing little benefit from the application of fertigation;

The Standard substrate promotes the smallest growth of the seedlings, proving to be an unsuitable substrate for seedling production in cone-tainers. Despite producing the smallest S. saman seedlings, this substrate evidences the effect of inoculation with NFB and AMF on plant growth. However, it does not prove to be the best for the mutual benefit of the symbionts.

\section{SUBMISSION STATUS}

Received: 21 May 2021

Accepted: 23 Aug. 2021

Associate editor: João Vicente de Figueiredo Latorraca

\section{CORRESPONDENCE TO}

\section{Gustavo Abaurre}

BR 465, Km 07, Jardim Botânico, Campus da UFRRJ, CEP 23897-000, Seropédica, RJ, Brasil

e-mail: gwabaurre@gmail.com

\section{AUTHORS' CONTRIBUTIONS}

Gustavo Wyse Abaurre: Conceptualization (Equal); Data curation (Equal); Formal analysis (Equal); Investigation (Equal); Methodology (Equal); Project administration (Equal) Validation (Equal); Visualization (Equal); Writing-original draft (Equal); Writing-review \& editing (Equal).

Orivaldo José Saggin Júnior: Conceptualization (Equal); Formal analysis (Equal); Investigation (Equal); Project administration (Equal); Supervision (Equal); Writing-original draft (Equal); Writing-review \& editing (Equal).

Sergio Miana de Faria: Conceptualization (Equal); Formal analysis (Equal); Investigation (Equal); Methodology (Equal); Project administration (Equal); Supervision (Equal); Visualization (Equal); Writing-original draft (Equal); Writingreview \& editing (Equal).

\section{REFERENCES}

Abaurre GW, Saggin Júnior OJ, Schäfer G, de Faria SM. (2020). Substrates for the production of Samanea saman (Jacq.) Merr seedlings inoculated with nitrogen-fixing bacteria and arbuscular mycorrhizal fungi. Symbiosis 2020; 1-7. https://doi.org/10.1007/ s13199-020-00707-7

Andraus M, Cardoso AA, Ferreira ME, Brasil EPF. Produção de mudas florestais inoculadas com rizóbios e fungos micorrízicos em blocos de resíduos agroindustriais. Nativa 2020; 8(2): 269-279. http://dx.doi.org/10.31413/nativa.v8i2.7843

Barwick M, Van Der Schans A, Claudy JB. Tropical and subtropical trees: a worldwide Encyclopaedic guide. London: Thames \& Hudson; 2004

BRASIL. Instrução Normativa SDA n. 13, de 24 de março de 2011. Diário Oficial da República Federativa do Brasil, Brasília, DF (2011 mar. 25); Sec. 1: 3-4.

Cabreira GV, Leles PS dos S, Alonso JM, Abreu AHM, Arthur Junior JC, Gusmão AVV, Lopes N. F. Fertilization and containers in the seedlings production and post-planting survival of Schizolobium parahyba. Ciência Florestal 2019; 29(4) 1644-1657.

Caldeira MVW, Favalessa, M, Gonçalves EO, Delarmelina WM, Santos FEV, Vieira M. Lodo de esgoto como componente de substrato para produção de mudas de Acacia mangium Willd. Comunicata Scientiae 2014; 5(1): 34-43.

Carneiro MA, Siqueira JO, Moreira FM, Carvalho DD; Botelho AS, Saggin-Junior OJ. Micorriza arbuscular em espécies arbóreas e arbustivas nativas de ocorrência no sudeste do Brasil. Cerne 1998; 4(1): 129-145.

de Faria SM, de Carvalho B, Paula RR, Santos FM, Zilli JE. Biological Nitrogen Fixation (BNF) in Mixed-Forest Plantations. In: Cardoso EJBN, Gonçalves JLM, Balieiro FC, Franco AA, editores. Mixed Plantations of Eucalyptus and Leguminous Trees. Springer: Cham; 2020. https://doi.org/10.1007/978-3-030-32365-3_6

de Faria SM, Diedhiou AG, de Lima HC, Ribeiro RD, Galiana A, Castilho AF, Henriques JC. Evaluating the nodulation status of leguminous species from the Amazonian forest of Brazil. Journal Of Experimental Botany 2010; 61(11): 3119-3127. 
de Oliveira GKV. Barbosa LDS, Bezerra AC, Nascimento KLD, Bezerra CVDC, Bezerra AB. Produção de mudas florestais nativas e frutíferas. In: VI Congresso Latino Americano de Agroecologia. Brasília: Cadernos de Agroecologia; 2018.

Delarmina WM, Caldeira MVW, Faria JCT, Gonçalvez EO, Rocha RLF. Diferentes substratos para a produção de mudas de Sesbania virgata. Floresta e Ambiente 2014; 21(2): 224-233.

Dobereiner, J. Nodulação e fixação de nitrogênio em leguminosas florestais. Pesquisa Agropecuária Brasileira 1984; 19(13): 83-90.

dos Santos NKF, Maneschy RQ. Avaliação de espécies madeireiras em sistemas agroflorestais familiares. Cadernos de Agroecologia 2016; 10(3): 15-25.

Ferreira RFL, Clebyane SB, Neila CLF. Crescimento e qualidade de mudas de cubiuzeiro (Solanum sessiliflorum Dunal) com uso de substratos em Rio Branco, Acre. Scientia Naturalis 2019; 1(5): 45-55.

Fijalkowski, K. \& Kwarciak-Kzlowska, A. Sewage Sludge as Soil Conditioner and Fertilizer. Enhanced Sustainable Remediation Technology 2021; 7(2): 283-297. https://doi. org/10.1002/9781119670391.ch14

Freire JM, de Faria SM, Zilli JE, Saggin-Junior OJ, Camargo IS, Rouws JRC, Jesus EDC. Symbiotic efficiency of inoculation with nitrogenfixing bacteria and arbuscular mycorrhizal fungi in Tachigali vulgaris SEEDLINGS. Revista Árvore 2020; 44: 1-11. doi.org/10.1590/1806908820200000024

Gerdemann JW, Nicolson TH. Spores of mycorrhizal endogone species extracted from soil by wet sieving and decanting. Transactions of the British Mycological Society 1967; 46(2): 235-244.

Góes LG, Quintela MF. Florística e estrutura de um reflorestamento no maciço da Tijuca, Rio de Janeiro, RJ, Brasil. Revista Internacional de Ciências 2015; 5(1): 106-126.

Gonçalves EO, Petri GM, Caldeira MVW, Dalmaso TT, Silva AG. Crescimento de mudas de Ateleia glazioviana em substratos contendo diferentes materiais orgânicos. Floresta e Ambiente 2014; 21(3): 339-348.

Grace C, Strible YDP. A safer procedure for routine staining of vesicular-arbuscular mycorrhizal fungi. Mycological Research 1991; 95(10): 1160-1162.

Hoffman LV, Lucena V. Para entender Micorrizas Asbusculares. 1 rd ed. Embrapa Algodão-Documentos (INFOTECA-E): Campina Grande; 2006

INVAM (International Culture Collection of Vesicular Arbuscular Mycorrhizal Fungi). The Fungi - Classification - Classification of Glomeromycota. [cited 2020 abr 4] Avaliable from: http://fungi. invam.wvu.edu/the-fungi/species-descriptions.html

Jenkins WR. A rapid centrifugal-flotation technique for separating nematodes from soil. Plant Disease Report 1964; 48(9): 692.

Kämpf AN. Produção comercial de plantas ornamentais. 1rd ed. Guaíba: Agrolivros; 2005.

Kishinami R, Shigueo WJ. Quanto o Brasil precisa investir para recuperar 12 milhões de hectares de florestas?: sumário executivo. 1rd ed. Instituto Escolhas: São Paulo; 2016.

Koske RE, Gemma JN. A modified procedure for staining roots to detect VA mycorrhizas. Mycological Research 1989; 92(4): 486-488.

Lima Filho P, Leles PSDS, Abreu AHMD, Silva EVD, Fonseca ACD. Produção de mudas de Ceiba speciosa em diferentes volumes de tubetes utilizando o biossólido como substrato. Ciência Florestal 2019; 29(1): 27-39.

Lorenzi H. Árvores brasileiras: manual de identificação e cultivo de plantas arbóreas do Brasil. Nova Odessa: Instituto Plantarum; 1998.

McGonigle TP, Miller MH, Evans DG, Fairchild GL, Swan JA. A new method which gives an objective measure of colonization of roots by vesicular-arbuscular mycorrhizal fungi. New Phytologist 1990; 115(3): 495-501.

Mendes MMC, Chaves LDFDC, Pontes Neto TP, Silva JAAD, Figueiredo MDVB. Crescimento e sobrevivência de mudas de sabiá (Mimosa caesalpiniaefolia Benth.) inoculadas com micro-organismos simbiontes em condições de campo. Ciência Florestal 2013; 23(2): 309-320. https://doi.org/10.5902/198050989277

Nascimento MPSCB, Oliveira MEA. Quebra de dormência de sementes de quatro leguminosas arbóreas. Acta Botanica Brasilica 1999; 13(2): 129-137.

Nogueira ADA, Machado PLOA, do Carmo CDS, Ferreira JR. Manual de laboratórios: solo, água, nutrição vegetal, nutrição animal e alimentos. 1rd ed. São Carlos: Embrapa Pecuária Sudeste; 1998.

Nogueira PDM, Júnior DGS, Ragagnin VA. Clorofila foliar e nodulação em soja adubada com nitrogênio em cobertura. Global Science and Technnology 2010; 3(2): 117-124.

Prasad RN, Viswanathan S, Devi JR, Nayak V, Swetha VC, Archana VR. Preliminary phytochemical screening and antimicrobial activity of Samanea saman 2008. Journal of Medicinal Plants Research; 2(10): 268-270.

Primieri S, Santos JCP, Antunes PM. A co-inoculação com fungos micorrízico arbusculares e bactérias fixadoras de nitrogênio é altamente benéfica para a Mimosa scabrella. In: XXXV Congresso Brasileiro de Ciência do Solo; Natal. Brasilia: CNPQ; 2015. 1-5.

Santos CBD, Longhi SJ, Hoppe JM, Moscovich FA. Efeito do volume de tubetes e tipos de substratos na qualidade de mudas de Cryptomeria japonica (LF) D. Don. Ciência Florestal 2000; 10(2): 1-15.

Santos JGD. Riqueza de fungos micorrízicos arbusculares no solo e o crescimento inicial de espécies arbóreas nativas [Tese]. Minas Gerais: Universidade Federal de Lavras; 2008

Scaramuzza CADM, Senta MMD, Ferrarini OG, Strassburg BBN, Hanson C. Elaboração da proposta do plano nacional de recuperação da vegetação nativa. In. da Silva APMS, Marques HR, Sambuich RHR. Mudanças no código florestal brasileiro: Desafios para a implementação da nova lei. IPEA: Rio de Janeiro; 2016.

Silva TJ, Alonso JM, Leles PSS, Abel ELS, Ribeiro JG, Santana JES. Mudas de Luehea divaricata produzidas com biossólido de duas estações de tratamento de esgoto. Advances in Forestry Science 2019; 6(2): 595-601.

Simões D, da Silva RBG, da Silva MR. Composição do substrato sobre o desenvolvimento, qualidade e custo de produção de mudas de Eucalyptus grandis Hill ex Maiden $\times$ Eucalyptus urophylla ST Blake. Ciência Florestal 2012; 22(1): 91-100.

Smith FA, Smith SE. Structural diversity in (vesicular)- arbuscular mycorrhizal symbioses. New phytologist 1997; 137(1): 373-388.

Staples GW, Craig RE. Samanea saman (rain tree) - Species profile for Pacific Island agroforestry. (2006) [cited $2020 \mathrm{dec}$. 13]. Avaliabre from: http://www.pakbs.org/pjbot/PDFs/40(5)/PJB40(5)2041.pdf 